\title{
Facile preparation of self-assembled wool-based graphene hydrogels by electron beam irradiation
}

\author{
Mira Park ${ }^{1}$, Bishweshwar Pant ${ }^{2}$, Jawun Choi ${ }^{2}$, Yong Wan Park ${ }^{3}$, Chohye Lee ${ }^{2}$, Hye Kyoung Shin ${ }^{4}$, \\ Soo-Jin Park ${ }^{4, \AA}$ and Hak-Yong Kim ${ }^{2, \$}$ \\ ${ }^{1}$ Department of Organic Materials and Fiber Engineering, Chonbuk National University, Jeonju 561-756, Korea \\ ${ }^{2}$ Department of BIN Fusion Technology, Chonbuk National University, Jeonju 561-756, Korea \\ ${ }^{3}$ Korea Institute for Knit Industry, Iksan 570-330, Korea \\ ${ }^{4}$ Department of Chemistry, Inha University, Incheon 402-751, Korea
}

\section{Article Info}

Received 16 March 2014

Accepted 27 March 2014

*Corresponding Author
E-mail: khy@jbnu.ac.kr
sjpark@inha.ac.kr

Tel: $+82-63-270-2351$

$+82-32-876-7234$

Open Access

DOI: http://dx.doi.org/

10.5714/CL.2014.15.2.136

This is an Open Access article distributed under the terms of the Creative Commons Attribution Non-Commercial License (http://creativecommons.org/licenses/ by-nc/3.0/) which permits unrestricted non-commercial use, distribution, and reproduction in any medium, provided the original work is properly cited.

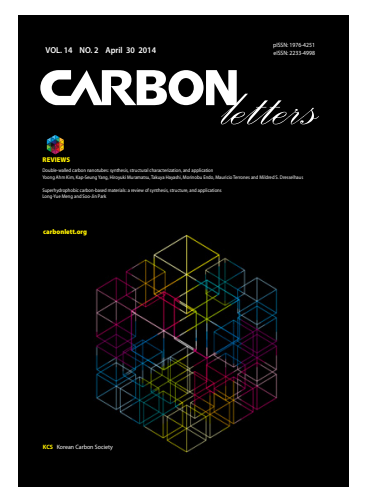

http://carbonlett.org

pISSN: 1976-4251

elSSN: 2233-4998

Copyright $\odot$ Korean Carbon Society

\begin{abstract}
Three dimensional self-assembled graphene hydrogels were easily fabricated by electron beam irradiation (EBI) using an aqueous solution of wool/poly(vinyl alcohol) and graphene oxide (GO). After exposure to various levels of EBI radiation, the highly porous, self-assembled, wool-based graphene hydrogels were characterized using scanning electron microscopy and Fourier-transform infrared spectroscopy; to determine the gel fraction, degree of swelling, gel strength, kinetics-of-swelling analyses and removal of hexavalent chromium $(\mathrm{Cr}(\mathrm{VI}))$ from the aqueous solution. X-ray diffraction results confirmed that EBI played a significantly important role in reducing $\mathrm{GO}$ to graphene. The adsorption equilibrium of $\mathrm{Cr}(\mathrm{VI})$ was reached within $80 \mathrm{~min}$ and the adsorption capacity was dramatically increased as the acidity of the initial solution was decreased from $\mathrm{pH} 5$ to 2 . Changes in ionic strength did not exert much effect on the adsorption behavior.
\end{abstract}

Key words: self-assembly, wool, graphene, electron beam

\section{Introduction}

Graphene is a two-dimensional, one-atom-thick honeycomb lattice sheet of $\mathrm{sp}^{2}$ carbon atoms. Since the discovery and subsequent development of graphene $[1,2]$, tremendous research has been focused on it due to its large theoretical specific-surface area, strong mechanical properties, excellent thermal and electrical conductivity, and relatively low density [3]. Furthermore, self-assembly is a promising strategy for fabricating graphene-based carbon materials for sensors and catalysis, as well as for energy storage and conversion. Two dimensional (2D) self-assembly of functionalized graphene has been accomplished by means of flow-directed self-assembly [4], evaporation-induced self-assembly [5], the Langmuir-Blodgett technique [6], and layer-by-layer deposition [7]. Recently, 3D carbon aerogels have been obtained by simple assembly of graphene oxide (GO) sheets [8,9]. Compared to traditional carbon aerogels, graphene-based aerogels exhibit ultralow density, high surface area and a very highly porous structure. Typical graphene/carbon composite aerogels were obtained by pyrolysis at $900^{\circ} \mathrm{C}$ for $2 \mathrm{~h}$ after typical synthesis of polymer solution at $180^{\circ} \mathrm{C}$ for $24 \mathrm{~h}$ and freeze-drying of the resulting hydrogels [8,9]. Making such freeze-dried, pyrolyzed products is time-consuming and requires an expensive process. Of unusual interest is a report of a process using electron beam irradiation (EBI) techniques that provided products that were nontoxic (without post-processing), used an environmentally friendly procedure, and exhibited the combined effects of cross-linking and sterilization [10]. Moreover, the EBI technique is also useful for modifying the physico-chemical properties of carbon materials. For instance, Park et al. [11] reported that the EBI exposures (50 kGy) resulted in the 
D to $G$ band intensity ratio of $1.01\left(\mathrm{I}_{\mathrm{D}} / \mathrm{I}_{\mathrm{G}}\right)$ due to the transformation of graphene from the nanocrystalline to the amorphous form. Finally, although reports on poly(vinyl alcohol)-blended hydrogels are numerous, to date, there are only a few reports on wasted-wool-based hydrogels.

Here we report the preparation of self-assembled, wool-based graphene hydrogels as a 3D structure for graphene-based materials. We also report the results of our study of the corresponding mechanical properties, gel fraction, swelling behavior, and hexavalent chromium (Cr(VI)) removal from aqueous solution. We attempted to save time and costs in producing hydrogels using EBI. Properties of self-assembled graphene hydrogels are rarely studied, so this information is of great interest for developing preparations of promising, environmentally friendly, lowcost graphene hydrogels.

\section{Experimental}

\subsection{Materials}

Urea, sodium disulfite $\left(\mathrm{Na}_{2} \mathrm{~S}_{2} \mathrm{O}_{5}\right)$, sodium dodecyl sulfate (SDS), acetone $\left(\mathrm{CH}_{3} \mathrm{COCH}_{3}\right)$, ethanol $\left(\mathrm{C}_{2} \mathrm{H}_{5} \mathrm{OH}\right)$, poly(ethylene imine) (PEI, branched, average $\mathrm{M}_{\mathrm{n}} \sim 10000$ by gel permeation chromatography, average $M_{w} \sim 25000 \mathrm{~g} / \mathrm{mol}$ by light scattering), PVA (Mw = $85000-124000 \mathrm{~g} / \mathrm{mol}, 87-89 \%$ hydrolyzed) and potassium dichromate $\left(\mathrm{K}_{2} \mathrm{Cr}_{2} \mathrm{O}_{7}\right)$ were purchased from the Sigma Aldrich, Co. (St. Louis, MO, USA). Wasted wool (Merino) was obtained from local bedding factories for free. Disposable sterilized polystyrene square dishes $(125 \times 125 \times 20 \mathrm{~mm})$ were purchased from SPL Life Sciences Co., Republic of Korea.

\subsection{Keratin extraction method (S-sulfo keratin)}

The wool was vigorously washed with water containing $0.5 \%$ SDS, rinsed and then air-dried. Keratin was extracted by sulfitolysis $[12,13]$. The wasted wool was then extracted using a Soxhlet apparatus and the dried-wool samples ( $150 \mathrm{~g}$ each $)$ were cut into snippets of a few millimeters each, and then placed into 1.5 liters of an aqueous solution containing $8 \mathrm{M}$ urea, $75 \mathrm{~g}$ of SDS and $150 \mathrm{~g}$ of $\mathrm{Na}_{2} \mathrm{~S}_{2} \mathrm{O}_{5}$. The mixture was heated to $100^{\circ} \mathrm{C}$, shaken for $30 \mathrm{~min}$ and then filtered through a stainless-steel mesh with pore sizes of $75 \mu \mathrm{m}$. The filtrate (molecular-weight cutoff of $12000 \mathrm{Da}$ ) was dialyzed using 15 liters of water that contained 0.1 wt $\% \mathrm{Na}_{2} \mathrm{~S}_{2} \mathrm{O}_{5}$, using cellulose tubing, for 3 days at $25^{\circ} \mathrm{C}$.

\subsection{Synthesis of GO}

GO was synthesized by a modified Hummers method [14]. Four grams of graphite flakes were added to a $250 \mathrm{~mL}$ flask containing $120 \mathrm{~mL}$ of $\mathrm{H}_{2} \mathrm{SO}_{4}$, which was then stirred for $1 \mathrm{~h}$. Fifteen grams of $\mathrm{KMnO}_{4}$ was gradually added to the mixture at intervals of $20 \mathrm{~min}$ (nine times). The mixture was slowly heated to $40^{\circ} \mathrm{C}$, and then maintained for $5 \mathrm{~h}$ in order to oxidize the graphite. Next, $150 \mathrm{~mL}$ of deionized (DI) water was added to the system. Finally, $15 \mathrm{~mL}$ of $\mathrm{H}_{2} \mathrm{O}_{2}$ solution was added to the mixture, stirred for $30 \mathrm{~min}$, and then left in this condition for $24 \mathrm{~h}$, after which it was centrifuged.

\subsection{Preparation of wool-based graphene hydrogels}

Hydrogels that contained the prepared keratin protein (5 wt $\%)$, PVA ( $5 \mathrm{wt} \%)$, GO (3 wt $\%)$, and DI water were produced in the form of a sheet $(125 \times 125 \times 5 \mathrm{~mm})$. To improve the gelation, $0.01 \mathrm{wt} \%$ PEI was included in the wool-PVAGO solution. Afterwards, the polymer solution was poured into the square dishes, and the dishes were irradiated with an electron-beam at a dose of 10-60 kGy. The irradiation of the samples was performed using an electron beam accelerator (beam energy $2.5 \mathrm{MeV}$, beam current $8.5 \mathrm{~mA}$, irradiation width $110 \mathrm{~cm}$, conveyor velocity $10 \mathrm{~m} / \mathrm{min}$, dose rate 6.67 $\mathrm{kGy} / \mathrm{s}$, and roller type handling system, EBTECH Co., Ltd., Korea) at room temperature, in air. The specific energy (SE) requirement in kilojoules per kilogram $(\mathrm{kJ} / \mathrm{kg})$ was equal to the dose in kilogray, as follows:

$$
\mathrm{SE}=\mathrm{D}(\mathrm{kJ} / \mathrm{kg})
$$

\subsection{Gel strength}

The tensile-strength-at-rupture and elongation-at-break were measured using a universal test machine (Lloyd, US/LRIOK) according to the ASTM D882 standard method. The data were transferred to a computer to evaluate the stress-strain curve. The gel strength was calculated using Eq. (2) [13].

Gel strength $(\mathrm{g} \cdot \mathrm{cm})=$

tensile strength at rupture $\times$ elongation at break

\subsection{Gel fraction}

The sample was dried at $60^{\circ} \mathrm{C}$ for $48 \mathrm{~h}$ to reach a constant weight (A) and then boiled in double-distilled water for $5 \mathrm{~min}$ before being dried again to a constant weight (B). The \% gel fraction was calculated using Eq. (3).

$\%$ gel fraction $=(\mathrm{B} / \mathrm{A}) \times 100$

\subsection{Degree of swelling}

The sample was weighed $\left(\mathrm{w}_{1}\right)$, and placed in distilled water for $72 \mathrm{~h}$, weighed $\left(\mathrm{w}_{2}\right)$, dried, and weighed $\left(\mathrm{w}_{3}\right)$ again. The $\%$ water uptake was calculated using Eq. (4).

$$
\% \text { degree of swelling }=\left\{\left(\mathrm{w}_{2}-\mathrm{w}_{3}\right) / \mathrm{w}_{1}\right\} \times 100
$$

\section{8. $\mathrm{Cr}(\mathrm{VI})$ adsorption experiments}

$\mathrm{K}_{2} \mathrm{Cr}_{2} \mathrm{O}_{7}$ was used as the source of $\mathrm{Cr}(\mathrm{VI})$. Hydrogel (300 mg) was put into a vial containing $30 \mathrm{~mL} 200 \mathrm{ppm} \mathrm{Cr}(\mathrm{VI})$ solution, varying the $\mathrm{pH}$ for $12 \mathrm{~h}$. Adjustment of the $\mathrm{pH}$ of the $\mathrm{Cr}(\mathrm{VI})$ solutions was done using $0.2 \mathrm{M} \mathrm{HCl}$ or $0.2 \mathrm{M} \mathrm{NaOH}$. The removal percentage of $\mathrm{Cr}(\mathrm{VI})$ was calculated using Eq. (5), where $\mathrm{C}_{0}$ is the initial concentration of $\mathrm{Cr}(\mathrm{VI})$ in solution $(\mathrm{mg} / \mathrm{L})$, and $\mathrm{C}_{\mathrm{e}}$ is the equilibrium concentration $(\mathrm{mg} / \mathrm{L})$.

$\%$ removal $=\left\{\left(\mathrm{C}_{0}-\mathrm{C}_{\mathrm{e}}\right) / \mathrm{C}_{0}\right\} \times 100$ 
The kinetic adsorption was determined by taking out 0.1 $\mathrm{mL}$ samples of the $\mathrm{Cr}(\mathrm{VI})$ solution at different times, for each of which the adsorption capacity was calculated using Eq. (6); where $Q_{t}$ is the adsorption capacity at time $t, C_{0}$ is the initial concentration of $\mathrm{Cr}(\mathrm{VI})$ in solution $(\mathrm{mg} / \mathrm{L}), \mathrm{C}_{\mathrm{t}}$ is the concentration at time $\mathrm{t}(\mathrm{mg} / \mathrm{L}), \mathrm{m}$ is mass of adsorbent $(\mathrm{g})$, and $\mathrm{V}$ is the volume of solution (L). All experiments were performed at $25^{\circ} \mathrm{C}$.

$$
\mathrm{Q}_{\mathrm{t}}=\left\{\left(\mathrm{C}_{0}-\mathrm{C}_{\mathrm{t}}\right) / \mathrm{m}\right\} \mathrm{V}
$$

\subsection{Characterization}

The changes in the functional groups of the hydrogels were evaluated using Fourier-transform infrared spectroscopy (FTIR, Varian 1000 FT-IR Scimitar series; PIKE Technologies, USA) on freeze-dried samples. Freeze-dried hydrogel samples were coated with platinum (ion-sputter, Hitachi E-1010, Japan) under vacuum, and were used to investigate the morphology of the keratin protein hydrogels using a Jeol JSM-5900 scanning electron microscopy (SEM). The crystal structure of the hydrogels was estimated using X-ray diffraction (XRD, Rigaku D/ max-2500) with $\mathrm{Cu} \mathrm{K}_{\alpha}$ radiation $(40 \mathrm{kV}, 250 \mathrm{~mA})$. The removal of $\mathrm{Cr}(\mathrm{VI})$ was performed by atomic absorption spectrometry (AAS, Perkin-Elmer 3110).

\section{Results and Discussion}

\subsection{FT-IR study of the hydrogels}

Fig. 1 presents the FT-IR spectra of GO, wool, PVA, wool/ PVA hydrogels and wool/PVA/GO hydrogels. GO has hydroxyl (at 1049 and $3386 \mathrm{~cm}^{-1}$ ) and ether groups on both sides, with carboxyl groups (at $1736 \mathrm{~cm}^{-1}$ ) on the edge. At $1624 \mathrm{~cm}^{-1}$, the peak indicated unoxidized graphitic domains in GO, or the stretching vibrations of the $\mathrm{C}=\mathrm{C}$ bond. Typical, characteristic peaks of keratin proteins were observed, including those indicating the elastic vibration of the $\mathrm{C}=\mathrm{O}$ bond at $1625 \mathrm{~cm}^{-1}$ and the bending deformation of the $\mathrm{C}-\mathrm{N}-\mathrm{H}$ bond at $1520 \mathrm{~cm}^{-1}$ [15]. A broad band that appeared at $2900-3700 \mathrm{~cm}^{-1}$ belonged to $\mathrm{OH}$ groups, and bands of carboxyl and carbonyl groups were also observed at $1736 \mathrm{~cm}^{-1}$ and $1,616 \mathrm{~cm}^{-1}$, respectively [16]. Comparison of wool/PVA and wool/PVA/GO hydrogels, revealed that the locations of peaks for $\mathrm{C}-\mathrm{H}$ stretching $\left(2920 \mathrm{~cm}^{-1}\right),-\mathrm{OH}$ and $-\mathrm{NH}_{2}$

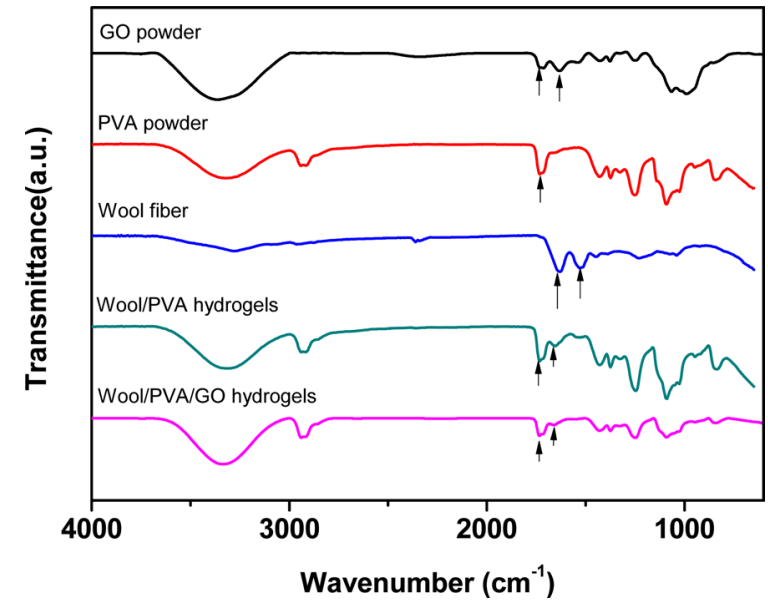

Fig. 1. Fourier-transform infrared spectra of graphene oxide (GO), poly(vinyl alcohol) (PVA), wool, wool/PVA and wool/PVA/GO hydrogels prepared at a dose of $30 \mathrm{kGy}$ in the presence of poly(ethylene imine).

(3700-3000 $\left.\mathrm{cm}^{-1}\right)$, and $\mathrm{C}=\mathrm{O}$ stretching $\left(1637 \mathrm{~cm}^{-1}\right)$ in $\mathrm{NHCO}$ were similar, and that most of the peaks compared were not significantly different. After adding GO to the polymer solution, the peaks for the oxygen functional groups did not increase and the peak at $1414 \mathrm{~cm}^{-1}$, corresponding to carboxy $\mathrm{C}-\mathrm{O}$, was almost eliminated by the EBI treatment. Furthermore, the peak at 1736 $\mathrm{cm}^{-1}$ for the wool/PVA/GO hydrogels decreased. These findings suggested that the functional groups of GO reacted with protein chains and played an important role in reducing GO to graphene when subjected to EBI.

\subsection{Characterization of the hydrogels}

The mechanical properties, gel fraction, and degree-of-swelling of the wool-based graphene hydrogels, and wool-based hydrogels, are shown in Table 1. The mechanical properties and water-absorption ratio of the hydrogels are normally influenced by the degree of cross-linking. The wool-based graphene hydrogels exhibited higher gel strength compared to wool-based hydrogels, when subjected to EBI doses of $20 \mathrm{kGy}$, with the highest gel strength of $689 \mathrm{~g} \cdot \mathrm{cm}$ observed at an EBI dose of $30 \mathrm{kGy}$. The gel strength of the wool/PVA/ GO hydrogels decreased as the EBI dose was increased from 30 to $60 \mathrm{kGy}$. The gel strength of the wool/PVA hydrogels decreased

\section{Table 1. Characterization of wool-based graphene hydrogels and wool-based hydrogels prepared using EBI at various radiation doses}

\begin{tabular}{ccccccccccc} 
Property & \multicolumn{4}{c}{ Wool-based graphene hydrogels } \\
\hline EBI dose $^{\text {a) }}$ & $10 \mathrm{kGy}$ & $20 \mathrm{kGy}$ & $30 \mathrm{kGy}$ & $40 \mathrm{kGy}$ & $60 \mathrm{kGy}$ & $10 \mathrm{kGy}$ & $20 \mathrm{kGy}$ & $30 \mathrm{kGy}$ & $40 \mathrm{kGy}$ & $60 \mathrm{kGy}$ \\
Gel strength $^{\text {b) }}(\mathrm{g} \cdot \mathrm{cm})$ & $402 \pm 11$ & $630 \pm 10$ & $689 \pm 15$ & $650 \pm 12$ & $621 \pm 12$ & $423 \pm 11$ & $635 \pm 20$ & $610 \pm 12$ & $602 \pm 15$ & $601 \pm 12$ \\
$\%$ Gel fraction $^{\mathrm{c})}$ & $76 \pm 3$ & $80 \pm 4$ & $82 \pm 5$ & $84 \pm 5$ & $85 \pm 4$ & $70 \pm 2$ & $75 \pm 4$ & $78 \pm 6$ & $79 \pm 5$ & $78 \pm 4$ \\
Degree of swelling $^{\text {d) }}(\mathrm{g} / \mathrm{g})$ & $36 \pm 3$ & $38 \pm 6$ & $40 \pm 5$ & $44 \pm 4$ & $43 \pm 3$ & $28 \pm 5$ & $30 \pm 4$ & $32 \pm 3$ & $31 \pm 4$ & $29 \pm 2$ \\
\hline
\end{tabular}

EBI: electron beam irradiation.

${ }^{a)}$ One kilogray (kGy) = 1 kilojoule (kJ)/kilogram (kg).

${ }^{\text {b) }}$ Gel strength $(\mathrm{g} \cdot \mathrm{cm})=$ tensile strength at rupture $\times$ elongation at break.

c) $\%$ gel fraction $=(B / A) \times 100$.

d) $\%$ degree of swelling $=\left\{\left(W_{2}-W_{3}\right) / W_{1}\right\} \times 100$. 


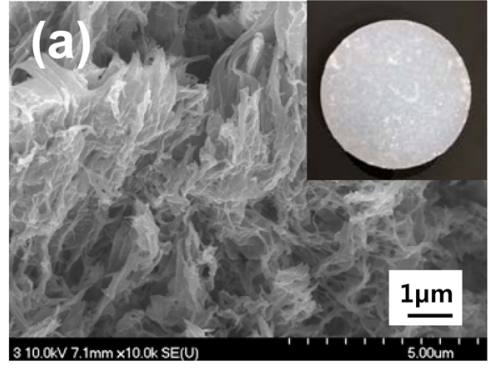

(c)

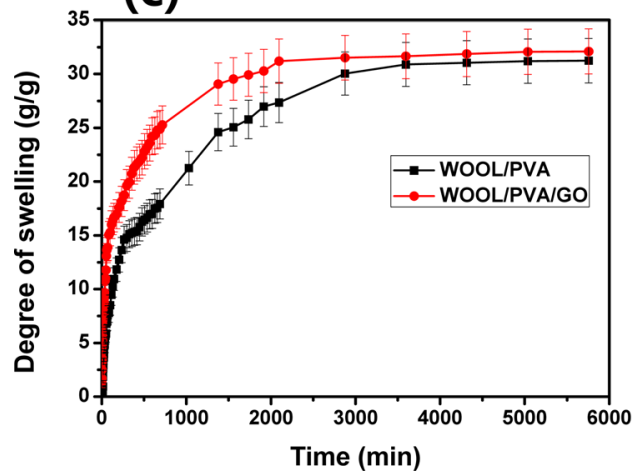

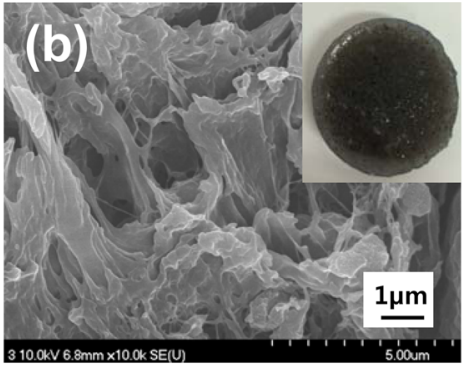

(d)

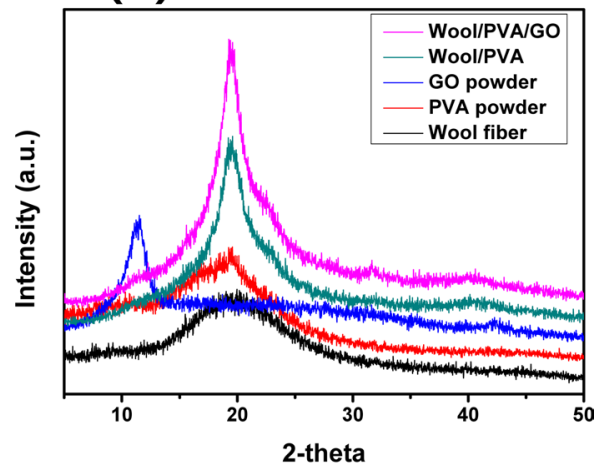

Fig. 2. Scanning electron microscopy micrographs of freeze-dried hydrogels produced from: (a) wool, and (b) wool/graphene oxide (GO) solutions blended with poly(vinyl alcohol) (PVA, keratin/PVA $=50 / 50, \mathrm{w} / \mathrm{w}$ ) at a dose of $30 \mathrm{kGy}$, in the presence of poly(ethylene imine) (0.01 wt $\%$ ); (c) swelling kinetics in water of wool/PVA and wool/PVA/GO hydrogels; and (d) X-ray diffraction patterns of samples. The inset shows photographs of hydrogels.

starting at a lower EBI dose (20 to $60 \mathrm{kGy})$. In our previous work [13], we observed that keratin-based/PVA hydrogels prepared using EBI exhibited a superior degree of swelling behavior, not only due to the considerable number of hydrophilic components produced upon irradiation (chemical water absorption), but also due to the highly porous structures (physical water absorption). Covalent cross-linking and physical cross-linking probably occurred coincidentally among the S-sulfo keratin main chains, oxygen groups in the PVA aqueous solution, GO, and amine groups of the PEI. Between the polymer chains, radicals were formed via direct or indirect reactions to the radiation, and to solvent-derived radicals. The gel fraction of the wool/PVA/GO hydrogels increased as the EBI dose was increased to $40 \mathrm{kGy}$, indicating a constant degree of cross-linking. The wool/PVA hydrogels presented probable predominating scission reactions, over cross-linking reactions, at EBI doses above $40 \mathrm{kGy}$.

\subsection{Surface morphology and structural analysis of hydrogels}

SEM images of the freeze-dried hydrogels produced from wool solutions blended with PVA and GO, in the presence of PEI, and at a dose of $30 \mathrm{kGy}$; were exhibited in Fig. 2. As seen in Fig. 2a, the freeze-dried wool/PVA/GO hydrogels clearly exhibited a more porous structure than the wool/PVA hydrogels. Furthermore, the wool/PVA/GO hydrogels also exhibited a considerably larger pore size than that of the wool/PVA hydrogels. A number of the physico-chemical properties (e.g., the gel fraction, degree of swelling, gel strength, and swelling kinet- ics) of the resulting hydrogels can be influenced by pore size [13]. The types and amounts of protein have probably influenced the morphological properties of the resulting hydrogels. Higher swelling capacities and higher swelling rates are required in practical applications. The swelling kinetics in water of wool/ PVA/GO and wool/PVA hydrogels is represented in Fig. 2c. The freeze-dried wool/PVA/GO hydrogels absorbed distilled water rapidly (more than $28 \mathrm{~g} / \mathrm{g}$ within $2000 \mathrm{~min}$ ) and then reached a plateau, whereas wool/PVA hydrogels absorbed approximately $25 \mathrm{~g} / \mathrm{g}$ in the same time. The swelling kinetics of superabsorbent polymers is influenced by the smaller pore size of the absorbents. However, the swelling behavior of the wool/PVA/GO and wool/PVA hydrogels was dominated by larger pore size after 30 min. This finding suggests that wool/PVA/GO hydrogels have the potential for practical applications because of their excellent swelling capacity and swelling kinetics. To further explore the structural changes of the distance of layers, a series of XRD analyses were carried out and the results presented in Fig. 2d. For the GO sample, an intense and sharp diffraction peak shows at $2 \theta=10.6^{\circ}$, corresponding to the (001) reflection [17]. Wool has a broad peak at $2 \theta=20.2^{\circ}$, and typical PVA at $2 \theta=19.5^{\circ}$. The XRD pattern of wool/PVA/GO hydrogels was similar to those of wool/PVA hydrogels, while the peaks characteristic of GO completely disappeared. A broad diffraction peak at around $2 \theta=21^{\circ}$, and a very weak peak at $2 \theta=44^{\circ}$ corresponding to the (100), suggested significant changes in the crystal structure of GO and confirmed again the reduction of GO. This is in accordance with the above FT-IR results for self-assembled, woolbased graphene hydrogels. 
(a)

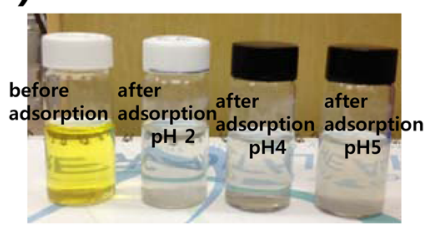



(c)

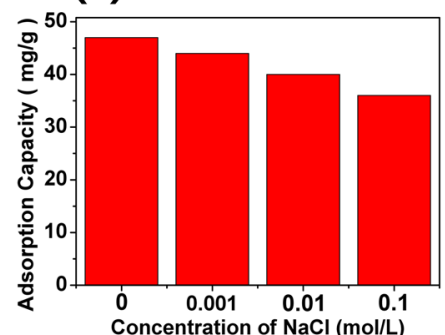

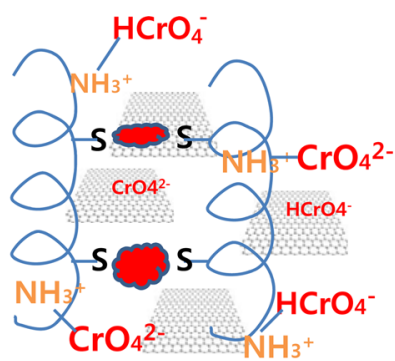

(d)

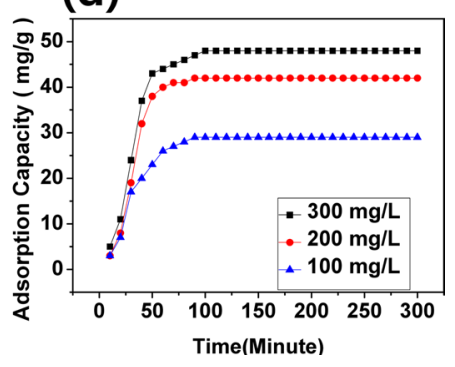

Fig. 3. Role and effects of $\mathrm{Cr}(\mathrm{Vl})$ : (a) schematic representation of its adsorption, (b) effect of $\mathrm{pH}$ on its removal, (c) effect of ionic strength on its removal performance, and (d) effect of contact time and initial concentration on its adsorption (at $25^{\circ} \mathrm{C}, \mathrm{pH} 2$ ) of self-assembled graphene hydrogels.

\subsection{Removal of $\mathrm{Cr}(\mathrm{VI})$ by self-assembled, wool-based graphene hydrogels}

A hypothetical schematic is presented in Fig. 3a. Wool comprises a three-dimensional mesh structure of keratin, which is composed of polypeptides with different amino acids, with inter-molecular bonding by disulfide cystine amino acids. Sulfur side-chains on the cysteine molecules after sulfitolysis of wool were bonded to another cysteine by the EBI. A slight shift of the typical absorption peaks for the $\mathrm{C}=\mathrm{O}$ and $\mathrm{C}-\mathrm{N}-\mathrm{H}$ bonds showed in the FT-IR spectra of the self-assembled, wool-based graphene hydrogels, due to intermolecular interactions and cross-linking reactions [13]. In Fig. 3b, the effect of $\mathrm{pH}$ on the adsorption of $\mathrm{Cr}(\mathrm{VI})$ is significant, and is possibly due to the amine groups in self-assembled, wool-based graphene hydrogels [18]. At $\mathrm{pH}$ 2.0-6.0, the predominant $\mathrm{Cr}(\mathrm{VI})$ species initially exists in the monovalent $\left(\mathrm{HCrO}_{4}^{-}\right)$form; then is gradually converted to the divalent $\left(\mathrm{CrO}_{4}{ }^{2-}\right)$ form by the increased $\mathrm{pH}$. As the $\mathrm{pH}$ increased, the uptake of $\mathrm{Cr}(\mathrm{VI})$ ions decreased because the higher concentration of $\mathrm{OH}^{-}$ions present in the aqueous solution competed with the $\mathrm{Cr}(\mathrm{VI})$ species $\left(\mathrm{CrO}_{4}{ }^{2-}\right)$ for the adsorption sites [18]. By adjusting the initial $\mathrm{pH}$ to 2.0 before adsorption, and by varying the concentration of $\mathrm{NaCl}$, the effect of ionic strength on the adsorption of $\mathrm{Cr}(\mathrm{VI})$ by self-assembled, wool-based graphene hydrogels was studied. The results are presented in Fig. 3c. The adsorption capacity remained approximately $82 \%$, whether with no $\mathrm{NaCl}$ or with $0.1 \mathrm{~mol} / \mathrm{L} \mathrm{NaCl}$. That is to say, the effect of ionic strength was not very great. The $\mathrm{Cr}(\mathrm{VI})$ adsorption kinetics, of hydrogels at $\mathrm{pH}$ 2.0, are shown in Fig. 3d. The adsorption capacity of $\mathrm{Cr}(\mathrm{VI})$ increased according to the adsorption time and concentrations of $\mathrm{Cr}(\mathrm{VI})$ solution. The equilibrium capacity was 29,41 , and $49 \mathrm{mg} / \mathrm{g}$ for 100,200 , and $300 \mathrm{mg} / \mathrm{L}$ of initial $\mathrm{Cr}(\mathrm{VI})$ solution, respectively. After $12 \mathrm{~h}$, the color of the $\mathrm{Cr}(\mathrm{VI})$ aqueous solution changed from yellow to colorless.

\section{Conclusions}

Here, we reported the preparation of self-assembled, woolbased graphene hydrogels to save time and costs in producing hydrogels. Promising, environmentally friendly, low-cost graphene hydrogels were successfully prepared by means of EBI and then used as an adsorbent for $\mathrm{Cr}(\mathrm{VI})$ ions from aqueous solution. The resulting self-assembled graphene hydrogels exhibit fibrous and highly porous morphologies and graphene structures, qualities confirmed by SEM and XRD analyses. These findings are in good agreement with the results of the FT-IR analysis. Such an EBI-induced self-assembly process for producing graphene offers a more convenient, more environmentally friendly and less expensive technique for large-scale applications.

\section{Acknowledgements}

This work was supported by a National Research Foundation of Korea (NRF) grant funded by the Korea government (Ministry of Education, Science and Technology, MEST, No. 2012R1A2A2A01046086). This work was also financially supported by MEST and NRF through the Human Resource Training Project for Regional Innovation (No. 201210A0404613010100).

\section{References}

[1] Novoselov KS, Geim AK, Morozov SV, Jiang D, Zhang Y, Dubonos SV, Grigorieva IV, Firsov AA. Electric field effect in atomically thin carbon films. Science, 306, 666 (2004). http://dx.doi. org/10.1126/science.1102896.

[2] Geim AK, Novoselov KS. The rise of graphene. Nat Mater, 6, 183 
(2007). http://dx.doi.org/10.1038/nmat1849.

[3] Geim AK. Graphene: status and prospects. Science, 324, 1530 (2009). http://dx.doi.org/10.1126/science.1158877.

[4] Chen H, Müller MB, Gilmore KJ, Wallace GG, Li D. Mechanically strong, electrically conductive, and biocompatible graphene paper. Adv Mater, 20, 3557 (2008). http://dx.doi.org/10.1002/ adma.200800757.

[5] Chen C, Yang QH, Yang Y, Lv W, Wen Y, Hou PX, Wang M, Cheng HM. Self-assembled free-standing graphite oxide membrane. Adv Mater, 21, 3007 (2009). http://dx.doi.org/10.1002/ adma.200803726.

[6] Li X, Zhang G, Bai X, Sun X, Wang X, Wang E, Dai H. Highly conducting graphene sheets and Langmuir-Blodgett films. Nat Nanotechnol, 3, 538 (2009). http://dx.doi.org/10.1038/nnano.2008.210.

[7] Shen JF, Hu YZ, Li C, Qin C, Shi M, Ye MX. Layer-by-layer selfassembly of graphene nanoplatelets. Langmuir, 25, 6122 (2009). http://dx.doi.org/10.1021/la900126g.

[8] $\mathrm{Hu} \mathrm{H}$, Zhao Z, Wan W, Gogotsi Y, Qiu J. Ultralight and highly compressible graphene aerogels. Adv Mater, 25, 2219 (2013). http://dx.doi.org/10.1002/adma.201204530.

[9] Qian Y, Ismail IM, Stein A. Ultralight, high-surface-area, multifunctional graphene-based aerogels from self-assembly of graphene oxide and resol. Carbon, 68, 221 (2014). http://dx.doi. org/10.1016/j.carbon.2013.10.082.

[10] Abad LV, Relleve LS, Aranilla CT, Dela Rosa AM. Properties of radiation synthesized PVP-kappa carrageenan hydrogel blends. Radiat Phys Chem, 68, 901 (2003). http://dx.doi.org/10.1016/ S0969-806X(03)00164-6.
[11] Park M, Shin HK, Kim BS, Pant B, Barakat NAM, Kim HY. Facile preparation of graphene induced from electron-beam irradiated graphite. Mater Lett, 105, 236 (2013). http://dx.doi. org/10.1016/j.matlet.2013.04.027.

[12] Aluigi A, Vineis C, Varesano A, Mazzuchetti G, Ferrero F, Tonin C. Structure and properties of keratin/PEO blend nanofibres. Eur Polym J, 44, 2465 (2008). http://dx.doi.org/10.1016/j eurpolymj.2008.06.004.

[13] Park M, Kim BS, Shin HK, Park SJ, Kim HY. Preparation and characterization of keratin-based biocomposite hydrogels prepared by electron beam irradiation. Mater Sci Eng C, 33, 5051 (2013). http:// dx.doi.org/10.1016/j.msec.2013.08.032.

[14] Hummers WS, Jr., Offeman RE. Preparation of graphitic oxide. J Am Chem Soc, 80, 1339 (1958). http://dx.doi.org/10.1021/ ja01539a017.

[15] Cardamone JM. Investigating the microstructure of keratin extracted from wool: peptide sequence (MALDI-TOF/TOF) and protein conformation (FTIR). J Mol Struct, 969, 97 (2010). http://dx.doi. org/10.1016/j.molstruc.2010.01.048.

[16] Li R, Liu C, Ma J. Studies on the properties of graphene oxide-reinforced starch biocomposites. Carbohydr Polym, 84, 631 (2011) http://dx.doi.org/10.1016/j.carbpol.2010.12.041.

[17] Zhang K, Zhang LL, Zhao XS, Wu J. Graphene/polyaniline nanofiber composites as supercapacitor electrodes. Chem Mater, 22 1392 (2010). http://dx.doi.org/10.1021/cm902876u.

[18] Hu J, Chen G, Lo IM. Removal and recovery of Cr(VI) from wastewater by maghemite nanoparticles. Water Res, 39, 4528 (2005) http://dx.doi.org/10.1016/j.watres.2005.05.051. 